\title{
Defining and delivering minimum incomes in China
}

\author{
Michael Adler"
}

\begin{abstract}
This paper combines an empirical analysis of national and international attempts to deal with the problem of poverty in China with a normative analysis of capability theory, as developed by Amartya Sen and Martha Nussbaum. In this way, it attempts to highlight the centrality of normative approaches to poverty and its elimination. The paper is in five parts. Section I analyses the history, development and effectiveness of social assistance under the Minimum Living Standards Scheme (MLSS) in China; Section II provides an outline of capability theory; Section III analyses the history, development and effectiveness of the United Nations Development Program's (UNDP) Millennium Development Goals, with a focus on the elimination of poverty in China; Section IV emphasises the importance of a capability approach to the measurement of poverty and outlines what needs to be done to reduce poverty in China; while Section $V$ discusses what still needs to be done to promote an effective anti-poverty strategy in China.
\end{abstract}

\section{Introduction}

The first aim of this paper is to assess the effectiveness of national legislation, in this case the Minimum Living Standards Scheme (MLSS), as an anti-poverty measure in China. We demonstrate that, as a national social assistance scheme, MLSS has several serious limitations: (I) the low level of financial support from central government means that there are considerable regional disparities; as a result, many poor people, especially in rural areas and especially in lessdeveloped regions, are not covered by MLSS; (2) migrant workers in urban areas are not covered by MLSS; (3) the level of benefits is very low indeed and central government has not established a national poverty line; and (4) even if the levels of benefit were higher, they would not be enough to lift people out of poverty because, in addition to income, poor people also need services, such as health care and education, and the cost of these services is not taken into account. Using capability theory, we then indicate how, using a 'bottom-up' approach, minimum standards, which take prevailing conditions into account, could be calculated. The second aim is to assess the extent to which the United Nations Millennium Development Goals which, in terms of their range, are based on capability theory, have resulted in a reduction in the extent of poverty in China. We show that, in the period ending in 2015, China's achievements in terms of poverty reduction were quite spectacular, although how this was achieved is unclear and there is still a great deal of poverty in China. The third aim is to discuss how it is possible to reach such disparate conclusions. Although the Chinese government has undoubtedly made considerable progress in reducing the extent of poverty, much remains to be done and we discuss whether and, if so how, internal and external pressures could put further pressure on the Chinese government. The paper concludes that this is unrealistic in contemporary China and suggests that the best way of putting pressure on the Chinese government to provide guidelines on how social assistance

* Emeritus Professor of Socio-Legal Studies in the School of Social and Political Science, Chrystal Macmillan Building, George Square, Edinburgh, EH8 ${ }_{2} \mathrm{LD}$, Scotland, UK. E-mail: michael.adler@ed.ac.uk. This paper is based on a lecture given at the South-Western University of Finance and Economics in Chengdu on 22 October 20I5. The author would like to thank Dr Xin Zhang for inviting him and the School of Law for its generous support. 
levels should be set is through international bodies like the United Nations Development Programme (UNDP) and the International Labour Organisation (ILO).

\section{MLSS in China'}

\subsection{History and context}

Following the establishment of the People's Republic of China (PRC) in I948, every able-bodied urban worker in a state-owned enterprise, state agency, government department or public-sector organisation was assigned to a work unit (danwel), which, in effect, constituted a 'mini welfare state'. The danwei system comprised three basic elements: full employment and job security (denoted by the term 'iron rice bowl'), an egalitarian wage (described as eating from a 'big rice pot') and a welfare package and, prior to the economic reforms of the I980s, more than 80 per cent of the urban labour force were covered by this system (Wong, I999). In rural areas, farmers worked for communes based on the collective ownership of land, through which daily necessities and basic medical care were distributed. For those urban residents who did not belong to a danwei, some social relief programmes were set up to take care of their basic needs and, in rural areas, a 'five guarantee' system, funded by local collectives, played the same role. Although the danwei system only provided a low level of welfare provision, it provided basic social protection for workers and farmers (Leung and Nunn, I995, cited in Ringen and Ngok, 2013).

The danwei system broke down after the Cultural Revolution (I966-1976) and, from I 978 onwards, a series of market-based reforms was introduced. In urban areas, the policy of full employment and job security was dismantled and replaced, in the mid-l98os, by a system of individual contracts. Stateowned enterprises (SOEs) were freed from their former responsibilities and large numbers of workers were laid off. Education, health care and housing were partially privatised and, for many people, became unaffordable. In rural areas, the dismantling of collective structures meant that social protection for most farmers evaporated. The resulting misery, in rural as well as urban areas, led to considerable social unrest in the late I980s and I99os (Ringen and Ngok, 2013).

The Chinese government responded by setting up a multi-tiered contributory social insurance scheme covering five main social risks: old age, unemployment, health care, maternity and workrelated injuries, and this became operational in the late I99os. Initially, social insurance was financed by employer contributions but, over time, individual contributions became more and more important (Li and Piachaud, 2006). However, because the new social insurance scheme was unable to cope with the mounting unemployment and urban poverty that had resulted from the shift from a centrally planned to a market-based economy and the breakdown of the old danwei system, it also set up a social assistance scheme to cope with these problems. MLSS is based on a Minimum Subsistence Guarantee and functions as a final safety net.

\subsection{The characteristics of MLSS}

Under MLSS, the rate of social assistance is based on measured expenses for daily necessities, namely on clothing, food and housing, in the local area, taking the financial circumstances of the provincial, municipal and county government into account. It was originally paid to the urban poor but was extended to the rural poor in 2007. In addition, there are some special programmes, such as medical aid, educational assistance and housing assistance, that are considered as supplements to MLSS. According to Ngok (2010), the development of MLSS can be divided into three stages: formation (I993-I997), extension (I997-2003) and consolidation (since 2003).

I This account draws on Ngok (2010). 
In the first stage, MLSS was a matter for provincial, municipal and county government. Beneficiaries were urban households with per capita incomes below the poverty line, determined using budget standard methods adjusted for local circumstances and taking into account the availability of funds. MLSS covered food, clothing and a few necessities such as fuel, electricity and water. It was expanded in 1997 to cope with the huge numbers of laid-off workers caused by the privatisation of SOEs.

By the end of I999, expenditure on and the number of recipients of MLSS were much greater than they had been in I993. However, only 4 million people, covering about 25 per cent of the urban poor, were covered, mainly due to the poor financial situation of many provincial, municipal and county governments. In late 200I, central government decided to speed up the development of MLSS and did this by contributing to the cost. By 2003, funding from central government made up 60 per cent of the cost of MLSS and this led to a big increase in the number of recipients. However, it did not lead to a corresponding increase in the level of social assistance.

In 2003, 22.47 million people in China, mainly in urban areas, were in receipt of MLSS. Priority was given to increasing the coverage of MLSS, although the level of protection was still very low. However, the main limitation was that rural poverty was an even more serious problem. In 2007, ten years after MLSS was set up in urban areas, central government extended it to rural areas and it is now available in all thirty-one provinces, autonomous regions and municipalities in China. Unfortunately, the level of assistance in rural areas is often extremely low.

\subsection{The limitations of MLSS}

As a national social assistance scheme, MLSS has four limitations. First, the low level of financial support from central government means that there are considerable regional disparities. This is because less-developed regions with limited financial resources have the largest number of poor people to support. As a result, many poor people, especially those who live in these regions, are not covered by MLSS. Second, migrant workers in urban areas - those who have come from rural areas to the cities to work ${ }^{2}$ but are still registered (under the Hukou system) as residents of rural areas - are not covered by MLSS (Cheng and Selden, I994). Third, the level of benefits is very low indeed and central government has not established a national poverty line. The I999 Regulations only stipulate that benefits should provide recipients with what is necessary for them to maintain a minimum standard appropriate for the local situation but do not indicate how this minimum standard should be calculated. This encourages provincial, municipal and county authorities to base their poverty lines on what they can 'afford', namely to set them in a 'top-down' manner. Moreover, central government has been more concerned with increasing the coverage of MLSS than with raising the level of benefits. Fourth, even if the levels of benefit were higher, they would not be enough to lift people out of poverty because, in addition to income, poor people also need services, such as health care and education, that are no longer free, and the cost of these services is not taken into account in calculating the minimum standard. It follows from this that, in spite of the spectacular growth of the Chinese economy, measured in terms of Gross Domestic Product (GDP), it is now the second largest economy in the world ${ }^{3}$ and, in spite of the Chinese government's impressive achievement of setting up and providing most of the funding for a national social assistance scheme, it is clear that millions of Chinese people are currently unable to achieve their capabilities and are, for this reason, unable to function effectively as full members of society. This reference to the notion of capabilities calls for some explanation.

2 Driven by the huge demand for cheap labour in urban areas, which has been fuelled by sustained economic growth, and by the poverty and lack of opportunity that are widespread in rural areas.

3 In 20I5, the GDP in China was I I,007.72 billion US dollars, equivalent to I 7.75 per cent of the world economy. It was higher than the GDP of Japan, Germany and the UK, but still substantially lower than that of the US, which was I8,036.65 billion US dollars, equivalent to 29.08 per cent of the world economy. 


\section{The notion of capabilities}

\subsection{Amartya Sen and the development of capability theory}

According to the Amartya Sen (I983), human needs comprise a set of capabilities and a set of commodities. The former refer to essential activities that all human beings need to perform while the latter refer to the resources, in cash or in kind, that they require if they are to do so. Capabilities comprise not only very basic activities such as eating and exercising enough to keep fit and healthy, which everyone would wish for themselves, but also more complex goals like enjoying personal autonomy, achieving self-respect and taking part in the life of the community. Sen claims that capabilities are universal and can be defined absolutely while commodities are relative. Thus, the commodity requirements of the universal set of capabilities vary over time and across societies.

Although Sen does not provide an exhaustive list of capabilities, preferring instead to allow them to remain implicit in his writing, they include meeting nutritional requirements, escaping avoidable disease, having shelter, being clothed, being able to travel, being educated, living without shame (recognised by Adam Smith, I776, I999), being able to participate in social activities (emphasised by Peter Townsend, 1979) and having self-respect (discussed by John Rawls, I972). While the commodity requirements of the capabilities at the beginning of the list of examples do not vary all that much between one society and another, those at the end of the list are extremely variable.

\subsection{Martha Nussbaum's version of capability theory}

Unlike Sen, Nussbaum (I997) does provide an explicit list of what she regards as the most important capabilities that should be the goal of public policy and could be given constitutional protection. Nussbaum's list of capabilities (I997, pp. 277-278) is set out in Table I.

In contrast to Sen, Nussbaum does refer to 'the right to employment', although it is only mentioned as one component of Capability Io. This is significant because of the importance of the right to employment in China. No significance should be attached to the order in which the capabilities are listed because Nussbaum makes it clear that they are all indispensable and all of central importance. However, she does accept that other people could come up with a different list of capabilities.

It will be noted that, while many of the capabilities in Nussbaum's list involve agency - what an individual should be able to do - some of them do not and are concerned with how an individual should be treated. Examples are freedom from being assaulted, being loved and cared for, and not being discriminated against by others. While the former are intrinsically bound up with the exercise of liberty, the latter are associated with the enjoyment of dignity.

\subsection{Similarities and differences between the two approaches}

Sen and Nussbaum both stress that 'basic' commodities comprise a set of thresholds and refer to what is needed for someone to achieve the capability in question, whether or not they choose to do so. So, for example, individuals need the resources to purchase a balanced diet even if they choose to be vegans and they need access to adequate housing even if they choose to live on the streets. Commodities only cover minimum needs and what people do on top of that is up to them.

One important difference between Sen's approach and Nussbaum's is that, while Sen refers to the 'commodities' and resources' that individuals require to achieve their capabilities, Nussbaum refers, in a more general way, to public policies that they require in order to live the life of 'a free and dignified human being'. These may include guarantees of various kinds - to freedom of speech and to freedom from discrimination that are required if individuals are to achieve their capabilities - and are not restricted to the provision of what are normally thought of as 'commodities' and 'resources'. 
Table I Nussbaum's list of capabilities

I LIFE

2

BODILY HEALTH

3

BODILY INTEGRITY

4

SENSES, IMAGINATION AND THOUGHT

5 EMOTIONS

6

PRACTICAL REASON

7 AFFILIATION, comprising FRIENDSHIP and RESPECT

\section{OTHER SPECIES}

9 PLAY

IO CONTROL OVER ONE'S ENVIRONMENT, comprising POLITICAL and MATERIAL capabilities
Being able to live to the end of a human life of normal length; not dying prematurely, or before one's life is so reduced as to be not worth living

Being able to have good health, including reproductive health; to be adequately nourished; to have adequate shelter

Being able to move freely from place to place; to be secure against violent assault, including sexual assault and domestic violence; having opportunities for sexual satisfaction and for choice in matters of reproduction

Being able to use the senses, being able to imagine, to think and to reason in a 'truly human way' ... being able to use one's mind in ways protected by guarantees of freedom of expression and freedom of religious exercise ... being able to have pleasurable experiences and to avoid non-beneficial pain

Being able to have attachments to things and people, to love those who love and care for us ... not having one's emotional development blighted by fear and anxiety

Being able to form a conception of the good, [which] entails protection of liberty of conscience and religious observance

Being able to engage in various forms of social interaction ... to have the capacity for justice and friendship, and having the social bases of selfrespect and non-humiliation, [which] entails provisions for non-discrimination on the basis of race, sex, ethnicity, caste, religion and national origin

Being able to live with concern for and in relation to animals, plants and the world of nature

Being able to laugh, to play and to enjoy recreation activities

Being able to participate effectively in political choices that govern one's life; having the right of political participation, protections of free speech and association, and being able to hold property (both land and material goods), having the right to employment, having freedom from unwarranted search and seizure

Nussbaum argues that the public policy requirements for the achievement of the capabilities in her list are best expressed in terms of rights but notes that 'what is involved in securing a right to people is usually a lot more than putting it down on paper'. Significantly, in her formulation, the familiar distinctions between positive rights and negative rights, and between civil and political rights, on the one hand, and economic, social and cultural rights, on the other, evaporate. 
It is important to emphasise that, as noted above, the capabilities referred to by Sen and Nussbaum represent thresholds - above the threshold, a person's capabilities are met, below it they are not. They represent minimum standards rather than the optimal standards to which people may aspire and which public policies, like social insurance, may seek to promote. The difference between the rights to minimum standards and rights to more optimal standards is that rights to minimum standards are human rights, which everyone should be entitled to on the grounds of their common humanity and which governments ought to guarantee, while rights to more optimal standards are citizenship rights that governments may choose to grant for those it represents on the basis of their citizenship. ${ }^{4}$ While countries will differ in the importance they attach to social rights as citizenship rights and in the levels of well-being they attempt to provide, the argument that is advanced in this paper is that all countries, whatever their political orientation, should seek to promote social rights as human rights, namely to minimise the extent of poverty and destitution. It follows from this that, irrespective of their social, economic and political arrangements or their level of development, countries can be compared in terms of the levels of poverty and destitution where these are based on the achievement of capabilities. One attempt to do so, which was strongly influenced by Sen and Nussbaum's work, was the Millennium Project, which was commissioned by the United Nations Secretary-General to develop a concrete plan of action plan for countries to achieve the Millennium Development Goals and to reduce the grinding poverty, hunger and disease that affect so many people.

\section{The Millennium Development Goals and the recently agreed Sustainable Development Goals}

\subsection{History and context}

The effectiveness of international conventions promoted by bodies like the ILO, and of the Millennium Development Goals (MDGs) and the recently agreed Sustainable Development Goals (SDGs) that replaced MDGs when they expired at the end of 2015, and the question of what, if anything, can be done to strengthen their effectiveness in securing a social minimum for everyone, especially in poorer countries, are clearly very important issues.

Following the United Nations' Millennium Summit in 2000, the MDGs were established in $200 \mathrm{I}$ and adopted by all members of the UN and by most the world's leading development institutions. They comprise the following eight goals, which were to be achieved by 2015:

I eradicating extreme poverty and hunger;

2 achieving universal primary education;

3 promoting gender equality;

4 reducing child mortality;

5 improving maternal health;

6 combating HIV/AIDS, malaria and other diseases;

7 ensuring environmental sustainability; and

8 developing a global partnership for development.

The eight goals were based on Amartya Sen's work on capabilities and the pre-conditions for human flourishing, although, as he lamented in a lecture, they were restricted to those conditions

4 There is an extensive literature on the concept of citizenship, much of it derived from a seminal essay by Marshall (1963). For a recent review of the major debates and criticisms that have been put forward since Marshall's essay was published, see Evers and Gillimard (2013), especially chapter I. 
that were measurable. Thus, they did not include references to other immeasurable but very important determinants of human flourishing, such as democracy and human rights (Sen, 20I2). Moreover, they are very wide in scope - much wider than measures such as GDP or GDP per head of population, which were formerly used as measures of development. Although the eight goals included an indicator of poverty and low income, they included much else besides.

The eight MDGs were associated with eighteen targets and forty-eight technical indicators for monitoring progress. The relationship between goals, targets and indicators as they apply to the first goal, namely to the eradication of poverty and hunger, is illustrated in Table 2.

It should be noted that many of the targets, such as the target referring to 'full' and 'productive' employment and 'decent' work, are rather vague and imprecise, while others, such as the targets referring to income or earnings of $\$ 1.00$ or $\$ 1.25$ per day, are arbitrary and, for this reason, quite unrelated to the achievement of capabilities, namely to what human beings need to do, in a given set of circumstances, to function effectively as members of the society in which they live (Sen, I989). Most of the targets refer to change, such as to the reduction of poverty and hunger, rather than to their abolition by exceeding or surpassing an appropriate target or threshold.

Progress towards the achievement of these goals has been uneven and, while some countries have achieved many of them, others have realised very few. However, according to a recent UNDP report, 'China's success provides an example for other [countries] to follow' (United Nations Development Programme China, 2015).

\subsection{China's performance}

In terms of a wide range of indicators, China's economic and social progress since I 980 has been quite remarkable. Most of the MDGs were either achieved and, where they were not, the country appears to be well on the way to achieving them. We focus here on poverty reduction.

According to the World Bank (2005), measured in terms of China's official poverty standard, namely in terms of the prevailing MLSS rate, the poverty rate in rural China fell from 18.5 per cent in I98I to 2.8 per cent in 2004 and the number of rural poor declined from I 52 million to 26

Table 2 Millennium Development Goals, targets and indicators

\section{GOAL I (ERADICATING EXTREME POVERTY AND HUNGER)}

\section{TARGETS}

Target IA: halving, between I990 and 2015, the proportion of people whose income is less than $\$ 1.00$ dollar a day (raised to \$I.25 in 2008)

Target I B: achieving full and productive employment and decent work for all, including women and young people

Target IC: halving, between I990 and 2015, the proportion of people who suffer from hunger

\section{INDICATORS FOR MONITORING PROGRESS}

I.I: proportion of population below \$I.Oo per day

(until 2008) or \$I.25 (since 2008)

I.2: poverty gap ratio

I.3: share of poorest quintile in national consumption

I.4: growth rate of GDP per person employed

I.5: employment-to-population ratio

I.6: proportion of employed people living below \$1.00 per day (until 2008) or \$I.25 (since 2008)

I.7: proportion of own-account and contributing family workers in total employment

r.8: Prevalence of underweight children under-five years of age

I.9: Proportion of population below minimum level of dietary energy consumption

Source: United Nations Statistics Division (2008) Official List of Millennium Development Goals Indicators. 
million. Measured in terms of the World Bank poverty standard of (888 yuan per person per year at 2003 rural prices), China's poverty-reduction performance was even more striking. Between I98I and 2004, the proportion of the population living below this poverty line fell from 65 per cent to Io per cent, and the absolute number of people who were poor fell from 652 million to I 35 million - a decline of over half a billion people. A fall of this magnitude over such a short period is quite remarkable. Measured in terms of the current international poverty standard of \$1.25 per person per day, the levels of poverty are higher, but the decline since I98I is no less impressive - levels of poverty fell from 85 per cent in I98I to 27 per cent in 2004 .

The rapid economic growth that resulted from the series of reforms adopted by the Chinese government as it engineered the transition from a centrally planned economy to a market-based economy has been central to poverty reduction. During the period I98I-2005, real per capita GDP grew at an average of 8.3 per cent per year, while the extent of poverty fell at an average of 7.I per cent per year. Thus, for every Io per cent increase in per capita GDP, there was a 9 per cent reduction in the incidence of poverty.

When the World Bank report was published in 2009, current estimates suggested that only about I per cent of China's population were living in extreme poverty. In other words, extreme poverty, in the sense of not being able to meet the most elementary food and clothing needs, had almost been eliminated in China. However, because the move from a centrally planned economy to a marketbased economy resulted in the monetisation and marketisation of many public services, most schools ${ }^{5}$ and health-care facilities ${ }^{6}$ now charge fees in order to cover their costs. This means that income has become more essential for meeting capabilities and for achieving minimum standards than was formerly the case. It follows from this that the official poverty standard needs to be raised above the current threshold, which enables the 'survival' needs of food and clothing to be met, to a new threshold, which would enable people to achieve a wider range of capabilities.

The Central Committee of the Chinese Communist Party (CCP) recently drew up proposals for the thirteenth five-year plan covering the period 20I6-2022 and an announcement by President $\mathrm{Xi}$ Jinping in October 2015 indicated that it would include a commitment to lift 70 million people above the national poverty line of 2,300 yuan per year.7 Although poverty in China is now an almost exclusively rural phenomenon, in that 99 per cent of those in poverty are registered (under the Hukou system) in rural areas, national statistics include migrant workers in cities among the rural poor rather that among the urban poor. But, even if migrant workers are excluded from the total, 90 per cent of those in poverty live in rural areas. And, even if differences in the cost of living between urban and rural areas are taken into account, their poverty still accounts for over 80 per cent of overall poverty. Thus, a commitment to lift 70 million people above the national poverty line of 2,300 yuan per year would represent most but not all of those living below the official poverty line.

Lifting 70 million people above the official poverty line would undoubtedly be an impressive achievement. However, it should be noted that there has been no suggestion that the official poverty line will be raised to a more realistic level. It follows that large numbers of people in China will still lack the means to achieve their capabilities and undertake those activities that all

5 Although tuition is free for the first nine years of compulsory schooling (comprising six years at a primary school and three years at a junior secondary school), parents are required to pay for textbooks and for a number of other items. Parents have to pay for tuition during three years at senior secondary school and, although some help is offered for poorer students, this seldom covers all costs.

6 Ninety-five per cent of the population has at least basic health insurance coverage but this only covers about half of medical costs, with the proportion lower for serious or chronic illnesses.

7 At the end of 20I4, 70.I4 million people in rural areas were reported to be living below the national poverty line. 
human beings need to perform in order to function effectively as members of society. There is likewise no commitment that procedures for determining how such a realistic poverty threshold should be set or what it would cover.

\section{Promoting an effective anti-poverty strategy}

In promoting an effective anti-poverty strategy, the Chinese government has clearly been in the driving seat. This is how it ought to be. The extent to which the MDGs made a difference is hard to determine. Whether a combination of governmental responsibility and international commitments is sufficient to ensure that poor people in China achieve a social minimum and that they are able to function effectively as members of society is open to question.

Whether or not to give constitutional protection to the right to a social minimum and, if so, whether or not to give people who fall below the social minimum, and/or organisations representing them, the right to challenge the government in the courts, with the aim of ensuring that governments give priority to the elimination of poverty and destitution, is an issue that is widely debated and one on which opinion is clearly divided (Gearty and Mantouvalou, 20II). Moreover, even it is thought to be desirable, there is the question of whether, in any particular society, such as China, it would be feasible.

Resources are, by definition, more limited in poorer societies and, where they are unequally distributed, large numbers of people will experience poverty, malnutrition and starvation and life expectancy is often shockingly low. However, China is no longer a poor society - in terms of GDP, it is now the second richest country in the world ${ }^{8}$ and, although, because of its enormous population, it is ranked lower in terms of GDP per capita, it is no longer among the poorest countries in the world. ${ }^{9}$ The Chinese government currently spends less than 0.5 per cent of its budget on MLSS (Ngok, 20I0) and it could clearly spend more. In addition, China has become an extremely unequal society according to Yu and Xiang (20I4), income inequality in China not only surpasses that of the US by a large margin, but also ranks among the highest in the world, especially when compared with countries that have comparable or higher standards of living. If income inequality was less, fewer people would probably experience poverty and deprivation and more people would be able to undertake those activities that they need to perform in order to function effectively as members of society.

Although the Chinese government has made considerable progress in emancipating citizens from the evils of poverty and destitution and enabling them to lead fulfilling lives, it is arguable that it could have made even more progress. What needs to be done to ensure that it continues to do so is also a matter of considerable dispute. Some individuals and organisations have argued that governments should be forced to ensure that everyone achieves a social minimum and that limits should be placed on their freedom to ignore the social rights of poor and vulnerable people for whom they are responsible. Giving constitutional protection to the right to a social minimum, which would, of course, need to be operationalised, and, as a last resort, allowing individuals and/ or organisations in civil society to challenge the government when it fails to deliver the social minimum is one possible strategy for preventing poverty, destitution and suffering in richer as well as poorer countries. However, others have cautioned against allowing legal challenges to the government when it fails to deliver the social minimum on the grounds that this is inherently

8 In 20I5, the GDP in China was I I,007.72 billion US dollars, equivalent to I 7.75 per cent of the world economy. It was higher than the GDP of Japan, Germany and the UK, but still substantially lower than that of the US, which was I8,036.65 billion US dollars, equivalent to 29.08 per cent of the world economy.

9 In 20I5, GDP per capita in China, after adjusting for purchasing power parity (PPP) was I 3,57 I.70 US dollars, equivalent to 76 per cent of the world's average. It was more than double that of India, which was 5,730.I4 US dollars. 
risky (in that it may result in adverse decisions that set back rather than advance the rights of poor people), that it often benefits the few (in particular those who can afford to raise a legal action or are fortunate enough to find an organisation to back them, rather than the many who are not in those positions) and that it is undemocratic (in that the judiciary does not have a democratic mandate). It is contended here that constitutional protection can play a role but that, because of the legitimate objections referred to above, it should only be invoked as a last resort and when a number of preconditions are met. Other constraints on national governments, like international conventions and the adoption of international targets, should normally play a larger role. This is the position taken by Jeff King (2012), who argues that, as long as there is a well-functioning system of courts and an independent judiciary, constitutionalising social rights and giving judges the power to adjudicate disputes between citizens and the state over the interpretation of these constitutional provisions are good ways of protecting the social rights of poor and vulnerable people. However, it should neither be the sole nor the main means for protecting the social rights of poor and vulnerable people - other constraints on national governments, like international conventions and the adoption of international targets, should normally play a larger role.

Whether or not China has a well-functioning system of courts is open to question (Jiang, 2006) but it is clear that China does not have an independent judiciary. Power in China is exercised by the CCP through the Central Committee, and its influence extends to every area of life, including the courts and the judiciary. According to the state-run China News Service, a recent meeting of the Supreme Court's Party Committee (The Guardian, 2015) has made it clear that a line should be drawn between China and West as far as notions of 'judicial independence' and 'separation of powers' are concerned, arguing that China should 'rr]esolutely resist the influence of the West's erroneous thought and mistaken viewpoints'. Its website reported that Zhou Qiang, China's Chief Justice and the President of its Supreme Court, had 'stressed the need to unswervingly take the road of socialism with Chinese characteristics' (The Guardian, 20I5). This is very much in line with President Xi Jinping's view that loosening party control too quickly, or even at all, would lead to chaos and the break-up of the country. It follows that, as things stand now and for the immediate future, allowing individuals and/or civil society institutions the right to challenge the constitutionality of governmental policies and/or their implementation, ${ }^{\text {Io }}$ and giving the courts the power to hold the government to account, is not on the agenda. However, the very fact that these issues have been discussed at this level indicates that it would be unwise to rule out such developments entirely. If the CCP were to loosen its grip and allow a liberalisation of the political system analogous to the liberalisation of the economy that has already taken place, then such developments could be up for discussion. Although China is clearly not yet ready to join countries like the Republic of South Africa and a number of Latin American countries in allowing individuals to challenge the constitutionality of alleged denials of socio-economic rights, this should not be ruled out indefinitely. ${ }^{\text {II }}$

\subsection{What needs to be done?}

The first priority for the Chinese government is probably to provide guidelines on how social assistance levels provided for by MLSS should be set by provincial, municipal and local governments. It is undoubtedly right that these levels should take local circumstances into

Io The rights set out in Chapter 2 of the Constitution of the PRC are relevant here. They include the right to personal dignity (Article 38); the right to work (Article 42); the right to material assistance from the state for those who are old sick or disabled and to social insurance (Article 45); and the right to education (Article 46).

I I For a wide-ranging collection of leading papers on this subject, see Fredman and Campbell (20I6). On the problems faced by poor people in challenging constitutionally guaranteed social rights, see Gargarella (20I4). 
account and that there should therefore be a degree of geographical variation. However, there has to be a standard set of procedures that would be applied. The second priority is to ensure that social assistance levels in MLSS enable recipients to achieve a wide range of capabilities, such as access to health care and education, in addition to minimum levels of food and clothing, and that the cost of doing so is taken into account. The eight MDGs all referred to measurable determinants of human flourishing and did not include any immeasurable goals, such as democracy and human rights (Sen, 20I2). This is unfortunate and needs to be corrected. Moreover, some of them, like the proportion of the population subsisting on less than $\$$ I.25 per day, are arbitrary and, for this reason, quite unrelated to the achievement of capabilities, while others, such as promoting gender equality or reducing child mortality, measure the direction of travel rather than the extent of the gap between people's lives and what they require to achieve their capabilities. The third priority, unrelated to the first two, is that the Chinese government needs to ensure that migrant workers are brought within the scope of MLSS.

Recent work on the measurement of capabilities (Anand et al., 2008; Hick, 20I2) has focused on which domains to include rather than how the extent to which the capabilities in these domains should be assessed. The latter calls for survey research, which would assess people's circumstances across all the domains that are included. Since this paper focuses on poverty, understood in terms of low income, data on individual or household income would then have to be compared with data on individual or household circumstances in each of the domains that were included. In this way, the income required, in a given social, economic and geographical context, for an individual or household to live the life of 'a free and dignified human being' could be calculated.

The distinctive characteristics of this approach are that it is a 'bottom-up' approach, and that it is based on empirical data on individual circumstances. These characteristics distinguish it from the approach that is currently used in China, and in most other countries, which is a 'top-down' approach based on a political assessment of the priority that should be given to poverty alleviation. Ideally, central government would provide a set of guidelines for provincial governments that would be mandated to conduct surveys of a representative sample of the population in urban and rural areas to determine what level of income is required to enable individuals to achieve an agreed set of capabilities. The social assistance levels that are used by MLSS would be then set at these levels. Given the disparities between standards of living in urban and rural areas and in different parts of the country, these levels would vary across China. In most, if not all, parts of the country, they would undoubtedly be higher than the prevailing levels of social assistance under MLSS today and would require a substantial increase in funding from central government.

The final issue is that of the best way of putting pressure on the Chinese government to adopt this approach to the setting of social assistance levels under MLSS. We have already discounted the possibility of using the courts now or in the immediate future. The other two possibilities involve internal pressure (through the Communist Party) and external pressure (through bodies such as the UNDP and the ILO). Most analysts would, in other countries, place more weight on national rather than international pressure but the difficulty of bringing influence to bear on the allpowerful Communist Party does not auger well for this strategy in China. Perhaps, in these circumstances, exerting pressure through international bodies stands a better chance of success, especially if they succeed in earning the trust of the national bodies with whom they work.

\section{References}

anand, P., santos, C. and smith, R. (2008) Poverty, Capabilities and Measurement. Oxford: Oxford University Press.

Cheng, T. and seldon, M. (I994) 'The Origins and Social Consequences of China’s Hukou System', The China Quarterly I39(September): 644-668. 
evers, Adelbert and gulllemard, Anne-Marie (2013) Social Policy and Citizenship: The Changing Landscape. Oxford: Oxford Scholarship Online. Available at: 〈http://www.oxfordscholarship.com/view/Io. I093/acprof:0so/9780199754045.00I.000I/acprof-9780199754045〉 (accessed I6 November 2017). FREDMAn, Sandra and CAmpbell, Megan (eds) (2016) Social and Economic Rights and Constitutional Law. Cheltenham: Edward Elgar Publishing.

GARGARella, Roberto (20I4) 'Latin American Constitutionalism: Social Rights and the "Engine Room" of the Constitution', Notre Dame Journal of International and Comparative Law 4(I): 9-I8.

Gearty, Conor and mantouvalou, Virginia (20I I) Debating Social Rights. Oxford: Hart Publishing. GUARDIAN, THE (2015) 'China's Top Court Rejects Judicial Independence as “Erroneous Thought”, 26 June. Available at: 〈https:/www.theguardian.com/world/2015/feb/26/chinas-top-court-rejectsjudicial-independence-as-erroneous-thought $\rangle$ (accessed I6 November 2017).

HICK, Rod (20I 2) 'The Capability Approach: Insights for a New Poverty Focus', Journal of Social Policy 4I (2): 29I-308.

JIANG, Qing-Yun (2006) Court Delay and Law Enforcement in China: Civil Process and Economic Perspective. Wiesbaden: Deutscher Universitäts-Verlag.

KING, Jeff (20I2) Judging Social Rights. Cambridge, Cambridge University Press.

Leung, J.C.B. and Nunn, R. (I995) Authority and Benevolence: Social Welfare in China. Hong Kong: China University Press, cited in Stein Ringen and Kinglun Ngok (2013) What Kind of Welfare State Is Emerging in China?, UNRISD Working Paper 2013-2. Geneva: United Nations Research Institute for Social Development.

LI, Bingqin and Piachaud, David (2006) 'Urbanisation and Social Policy in China', Asia-Pacific Development Journal I3(I): I-26.

marshall, T.H. (1963) 'Citizenship and Social Class' in T.H. Marshall (ed.) Sociology at the Crossroads. London: Routledge, chapter 4.

NGOK, Kinglun (20I0) 'Social Assistance Policy and Its Impact on Social Development in China: The Case of the Minimum Living Standards Scheme', China Journal of Social Work 3(I): 35-52. Available at:〈http://www.tandfonline.com/doi/abs/Io.I080/I7525090903560606〉 (accessed 28 October 2017).

nussbaum, Martha (1997) 'Capabilities and Human Rights', Fordham Law Review 66(2): 273-300. RAWLs, John (1972) A Theory of Justice. Oxford: Clarendon Press.

RINGEn, Stein and NGOK, Kinglun (2013) What Kind of Welfare State Is Emerging in China?, UNRISD

Working Paper 2013-2. Geneva: United Nations Research Institute for Social Development. SEN, Amartya (I983) 'Poor, Relatively Speaking', Oxford Economic Papers 35(July): I53-I69.

SEN, Amartya (I989) 'Development as Capability Expansion', Journal of Development Planning I 9(I): 4I58.

SEN, Amartya (2012) 'Human Development in the Post-20I5 Era', lecture delivered at the launch of the International Centre for Human Development at the Stein Auditorium, India Habitat Centre, New Delhi, 4 January. Available at: 〈http://www.in.undp.org/content/dam/india/docs/humandevelopment/Amarty\%20Sen\%2oLecture_\%2oHuman-Development-in-the-Post-2015-era.pdf > (accessed 28 October 2017).

Sмith, Adam (I776, I999) The Wealth of Nations, Books I-III. London: Penguin Books. townsend, Peter (I979) Poverty in the United Kingdom. Harmondsworth: Penguin Books.

United nations Development programme china (20I5) 'China's Success on Millennium Development Goals Provides an Example for Others to Follow for the Post-2015 Development Agenda', press release, I7 February. Available at: 〈http://www.undp.org/content/undp/en/home/presscenter/ articles/2015/02/I 7/china-s-success-on-millennium-development-goals-provides-an-example-forothers-to-follow-for-the-post-20 I5-development-agenda-says-new-undp-reporto.html> (accessed I6 November 2017). 
United NATIONS STATISTICS DIVISION (2008) Official List of Millennium Development Goals Indicators. Available at: 〈http://mdgs.un.org/unsd/mdg/Host.aspx?Content=indicators/officiallist.htm〉 (accessed 28 October 2017).

Wong, L. (I999) Marginalisation and Social Welfare in China. London: Routledge, cited in Stein Ringen and Kinglun Ngok (2013) What Kind of Welfare State Is Emerging in China?, UNRISD Working Paper 2013-2. Geneva: United Nations Research Institute for Social Development.

WORLd bank, THE (2009) China - From Poor Areas to Poor People: China's Evolving Poverty Reduction Agenda,

Report No. 47349-CN, 5 March. Available at: 〈http://documents.worldbank.org/curated/en/ 8I685I4682 I99I8783/China-From-poor-areas-to-poor-people-Chinas-evolving-poverty-reductionagenda-an-assessment-of-poverty-and-inequality> (accessed I6 November 2017).

YU, X. and XIANG, Z. (20I4) 'Income Inequality in Today's China', Proceedings of the National Academy of Sciences of the United States of America I I I(I9): 6928-6933. 